Ekonomia - Wroclaw Economic Review 27/2 (2021)

Acta Universitatis Wratislaviensis

No 4067

https://doi.org/10.19195/2658-1310.27.2.1

\author{
Tomasz Jedynak \\ ORCID: 0000-0003-4141-6654 \\ Uniwersytet Ekonomiczny w Krakowie \\ tomasz.jedynak@uek.krakow.pl
}

\title{
Uwarunkowania wykluczenia emerytalnego z dodatkowej części systemu emerytalnego w Polsce*
}

Artykuł nadesłany: 14.04.2020; artykuł zaakceptowany: 28.08.2021

Kody klasyfikacji JEL: J26, J32, H55

Keywords: retirement exclusion, pension exclusion, financial exclusion, exclusion determinants, pension system

\section{Abstract \\ Determinants of pension exclusion from the supplementary part of the Polish pension system}

The study addresses the issues of exclusion from the supplementary part of the Polish pension system. The main goals of the research are: 1) characterising retirement exclusion as a specific type of financial exclusion, and 2) identifying and assessing key determinants of retirement exclusion in the supplementary part of the Polish pension system. The article is epistemological and classifying in nature. In the review part, the research methods used are based on a critical analysis of the literature and a synthesis of its conclusions. The main part is based on a meta-analysis of the results of surveys regarding pension awareness and propensity to save, elements of the economic analysis of law, and analysis of existing data. The presented considerations lead to the formulation of arguments, that justify the thesis that the scale and extent of retirement exclusion in the supplementary part of the Polish pension system are a derivative of factors included in four meta-categories: 1. low pension awareness, 2 . low saving potential, 3 . low propensity to save, and 4 . limited availability of pension products.

* Projekt finansowany w ramach programu Ministra Edukacji i Nauki pod nazwą „Regionalna Inicjatywa Doskonałości” w latach 2019-2022, nr projektu: 021/RID/2018/19, kwota finansowania: 11897 131,40 PLN.

Ekonomia - Wroclaw Economic Review 27/2 (2021)

(C) for this edition by CNS 


\section{Wstęp}

Długoterminowe prognozy i symulacje jednoznacznie wskazują na istotny spadek adekwatności dochodowej polskiego systemu emerytalnego (OEDC, 2017; European Commission, 2018). Jako jedno z rozwiązań mających zwiększyć wysokość przyszłych świadczeń emerytalnych wskazuje się stymulację dobrowolnych oszczędności emerytalnych poprzez rozbudowę dodatkowej części systemu emerytalnego (Kawalec, Błażuk, Kurek, 2015; Rutecka, 2015). Okazuje się jednak, że pomimo ponad dwudziestoletniego funkcjonowania części dodatkowej w polskim systemie emerytalnym, stosowanych w jej ramach zachęt fiskalnych oraz prowadzonych akcji edukacyjnych, stopień wykorzystania instrumentów zaliczanych tradycyjnie do trzeciego filara jest znikomy. IKE ma zaledwie 5,9\% aktywnych ekonomicznie Polaków, IKZE - 4,3\%, a PPE 2,5\%. Średnia wysokość środków zgromadzonych na IKE wynosi 8,7 tys. PLN, na IKZE - 3,1 tys. PLN, a na PPE 30 tys. PLN ${ }^{1}$. Również pierwsze dane dotyczące uczestnictwa w pracowniczych planach kapitałowych (PPK) wskazują na niższe niż zakładane zainteresowanie tą formą gromadzenia oszczędności - partycypacja w przypadku przedsiębiorstw zatrudniających powyżej 250 pracowników jest szacowana na $40 \%$ uprawnionych, przy czym większość pracowników i pracodawców zdecydowała się na opłacanie składek minimalnych (Kolek, Wojewódka, 2019). W opracowaniu niski poziom upowszechnienia instrumentów dodatkowego oszczędzania na emeryturę jest analizowany przez pryzmat wykluczenia w dodatkowej części systemu emerytalnego.

\section{Teoretyczny aspekt badań}

W ujęciu mikroekonomicznym (jednostkowym) istotą funkcjonowania systemu emerytalnego jest wygładzenie konsumpcji w cyklu życia jego uczestników poprzez alokację w czasie ich dochodów (Blake, 2006; Chybalski, 2016, Góra, 2003). Ta alokacja dokonuje się w ramach dwóch faz uczestnictwa w systemie emerytalnym: fazy akumulacji, w której jednostka w zamian za rezygnację z części dochodu uzyskiwanego z tytułu wykonywanej pracy nabywa określone uprawnienia emerytalne, oraz fazy konsumpcji, w której uprzednio nabyte uprawnienia emerytalne stanowią podstawę do otrzymywania świadczeń emerytalnych (Szumlicz, 2005). Prezentowane spojrzenie na system emerytalny powoduje, że spośród stawianych mu celów na pierwszy plan wysuwa się zapewnienie adekwatności dochodowej $^{2}$. Za OECD (2013), adekwatność dochodowa systemu emerytalnego jest

1 Obliczenia własne na podstawie danych Komisji Nadzoru Finansowego (2019a, 2019b) i GUS (2019).

2 Poza adekwatnością dochodową do celów systemu emerytalnego zalicza się również efektywność i stabilność finansową systemu, które są jednocześnie gwarantem długoterminowej adekwatności emerytur (Chybalski, 2016). Wśród celów współczesnych systemów emerytalnych wy-

Ekonomia - Wroclaw Economic Review 27/2 (2021)

(C) for this edition by CNS 
rozumiana dalej jako jego zdolność do zapewnienia świadczeń umożliwiających utrzymanie wcześniejszego standardu życia po przejściu na emeryturę.

Dla dalszych rozważań istotne jest rozróżnienie bazowej (powszechnej) i dodatkowej części systemu emerytalnego. Części te, poza kryterium przymusu uczestnictwa (obowiązkowej lub dobrowolnej alokacji dochodu), odróżnia podstawowy cel funkcjonowania. W przypadku systemu bazowego jest to cel społeczny, który Marek Góra (2003) definiuje jako ,zapewnienie dochodu wszystkim osobom objętym tym systemem na cały okres po zakończeniu aktywności zawodowej”. Część dodatkowa, określana również jako dodatkowy system emerytalny (Rutecka, 2015; Szczepański, 2016; Uścińska, 2011), ma za zadanie zwiększenie elastyczności uczestnictwa w systemie emerytalnym oraz zwiększenie efektywności alokacji dochodu. Przyjmuje się, że emerytury finansowane w ramach bazowej części systemu mają zapewniać pewien określony, na ogół niższy od pożądanego standard życia po zakończeniu aktywności zawodowej. Podwyższenie poziomu dochodów na emeryturze - a więc zwiększenie adekwatności emerytur — jest natomiast główną przesłanką do istnienia dodatkowej części systemu emerytalnego (Góra and Rutecka, 2013; Rutecka, 2014). Idąc dalej, można zauważyć, że im niższe gwarantowane przez bazowy system emerytalny świadczenia, tym większe pole do funkcjonowania dodatkowych systemów emerytalnych (Jakubowski, 2019a).

Na dodatkową część systemu emerytalnego można spojrzeć w dwojaki sposób (Jedynak, 2014). W wąskim ujęciu składają się na nią wyłącznie promowane przez państwo poprzez system ulg i zwolnień podatkowych sformalizowane instrumenty oszczędzania na cele emerytalne. Patrząc szeroko, obok wspomnianych instrumentów można do niego zaliczyć również wszelkie inne oszczędności i inwestycje dokonywane z myślą o ich wykorzystaniu w okresie po zaprzestaniu aktywności zawodowej (na przykład aktywa na rynku kapitałowym, polisy ubezpieczeniowe, inwestycje w nieruchomości, dzieła sztuki). W opracowaniu przyjęto wąską perspektywę. W przypadku polskiego systemu emerytalnego, jako jego dodatkową część potraktowano więc trzy tradycyjnie zaliczane do trzeciego filara instrumenty gromadzenia dodatkowych oszczędności na cele emerytalne — Indywidualne Konta Emerytalne (IKE), Indywidualne Konta Zabezpieczenia Emerytalnego (IKZE) oraz Pracownicze Programy Emerytalne (PPE), a także niedawno wprowadzone Pracownicze Plany Kapitałowe (PPK).

Pojęciem nadrzędnym względem wykluczenia emerytalnego, będącego głównym przedmiotem rozważań w opracowaniu, jest wykluczenie finansowe. Termin ten najogólniej definiuje się jako brak dostępu bądź brak korzystania z usług finansowych (Iwanicz-Drozdowska, 2011). Z innej perspektywy wykluczenie finansowe jest natomiast określane jako proces, w którym obywatele doświadczają problemów w dostępie do i/lub korzystaniu z produktów oraz usług finanso-

mienia się także pomoc najuboższym członkom społeczeństwa, redystrybucję dochodów oraz realizację innych celów ekonomicznych i społecznych (Barr, Diamond, 2014).

Ekonomia - Wroclaw Economic Review 27/2 (2021) 
wych na głównym rynku (mainstream market), odpowiadających ich potrzebom i umożliwiających im prowadzenie normalnego życia w społeczeństwie (European Commission, 2008).

W kwestii konsekwencji wykluczenie emerytalne jest rozumiane jako częściowe pozbawienie środków finansowych po zakończeniu aktywności zawodowej (Kondzielnik, Majka, 2019). Natomiast bazując na definicji wykluczenia finansowego Małgorzaty Iwanicz-Drozdowskiej (2011), wykluczenie emerytalne można ogólnie zdefiniować jako brak dostępu lub brak korzystania z produktów emerytalnych. Podobnie stanowisko wyraża Mariusz Dybał (2019), który twierdzi, że wykluczenie emerytalne polega ,na utrudnieniu w korzystaniu lub wręcz niekorzystaniu z produktów emerytalnych, takich jak na przykład PPE, IKE czy IKZE”. W tym kontekście wykluczenie emerytalne można zatem rozpatrywać w ujęciu bezwzględnym (brak możliwości korzystania z produktów emerytalnych) oraz w ujęciu względnym (brak korzystania z produktów pomimo ich dostępności). Przyjmując szerszą perspektywę nawiązującą do przedstawionej istoty funkcjonowania współczesnych systemów emerytalnych, wykluczenie emerytalne można natomiast utożsamiać z nieodpowiednią alokacją dochodu w cyklu życia i wynikającym z niej brakiem adekwatności świadczeń emerytalnych (Jedynak, 2020).

Opierając się na koncepcji podziału systemu emerytalnego na część bazową i dodatkową, można wyróżnić wykluczenie emerytalne z systemu bazowego i wykluczenie z systemu dodatkowego. Wykluczenie z systemu bazowego wiąże się na ogół z brakiem nawet podstawowej alokacji dochodu w cyklu życia, a w konsekwencji brakiem środków do życia w okresie starości. Osoby wykluczone z bazowego systemu emerytalnego są więc w „okresie emerytalnym” zdane na świadczenia z zakresu pomocy społecznej. Konsekwencją wykluczenia z części dodatkowej systemu emerytalnego jest z reguły otrzymywanie świadczeń emerytalnych poniżej poziomu umożliwiającego utrzymanie wcześniejszego standardu życia. Ponieważ główna oś rozważań prezentowanych w opracowaniu koncentruje się na wykluczeniu z części dodatkowej systemu emerytalnego, zagadnieniu temu zostanie poświęcona szczególna uwaga.

Druga płaszczyzna analizy wykluczenia emerytalnego wynika z przyjęcia dwufazowego modelu uczestnictwa w systemie emerytalnym. Na jego podstawie wykluczenie emerytalne można podzielić na wykluczenie w fazie akumulacji uprawnień oraz w fazie konsumpcji. Pierwszy rodzaj wykluczenia wiąże się z brakiem gromadzenia uprawnień (oszczędności) emerytalnych. Drugi oznacza brak równomiernie rozłożonej na czas od zaprzestania aktywności zawodowej do śmierci konsumpcji zgromadzonego kapitału lub uprawnień emerytalnych. Wykluczenie w fazie akumulacji na ogół pociąga za sobą automatyczne wykluczenie z fazy konsumpcji, jednak nie zawsze musi tak być. Na przykład: osoba niegromadząca oszczędności emerytalnych po zaprzestaniu aktywności zawodowej może zdecydować się przeznaczyć zgromadzony wcześniej majątek na konsumpcję, wykorzystując do tego mechanizm odwróconego kredytu hipotecznego. Również ak-

Ekonomia - Wroclaw Economic Review 27/2 (2021)

(C) for this edition by CNS 
tywne gromadzenie uprawnień emerytalnych w fazie akumulacji niekoniecznie jest tożsame z brakiem wykluczenia w fazie konsumpcji. Dzieje się tak, gdy środki zgromadzone na cele emerytalne są wykorzystywane jednorazowo lub w krótkim czasie, co powoduje wykluczenie z konsumpcji w kolejnych latach. Natura omawianego podziału wykluczenia emerytalnego powoduje, że ma on praktyczne zastosowanie głównie w odniesieniu do wykluczenia z części dodatkowej systemu emerytalnego. W systemach bazowych zasady uczestnictwa $\mathrm{w}$ fazie akumulacji są bowiem ściśle związane z regułami obowiązującymi w fazie konsumpcji.

Przyczyny wykluczenia emerytalnego mogą mieć charakter egzo- bądź endogeniczny (Kondzielnik, Majka, 2019). Przyczyny egzogeniczne są pochodną czynników niezależnych od jednostki, takich jak na przykład formalna możliwość korzystania z produktów emerytalnych. Do przyczyn endogenicznych należą nieświadomość konieczności zabezpieczenia emerytalnego oraz niechęć do gromadzenia środków zabezpieczających na starość. Istotnym czynnikiem warunkującym korzystanie z produktów emerytalnych jest również możliwość generowania nadwyżek finansowych.

Pogłębione analizy prowadzą do wyróżnienia czterech kluczowych determinant wykluczenia emerytalnego z części dodatkowej systemu emerytalnego, przedstawionych w tabeli 1 (Jedynak, 2020). Wskazane determinanty należy przy tym traktować jako makro-kategorie, w ramach których zawiera się wiele czynników szczegółowych warunkujących wykluczenie emerytalne na poziomie jednostkowym.

Tabela 1. Determinanty wykluczenia emerytalnego z części dodatkowej systemu emerytalnego w Polsce

\begin{tabular}{|c|l|}
\hline \multicolumn{1}{|c|}{ egzogeniczne } & \multicolumn{1}{c|}{ endogeniczne } \\
\hline \multirow{4}{*}{ 1. dostępność produktów emerytalnych } & 2. potencjał oszczędnościowy \\
\cline { 2 - 2 } & 3. świadomość emerytalna \\
\cline { 2 - 2 } & 4. skłonność do oszczędzania \\
\hline
\end{tabular}

Źródło: opracowanie własne.

Układ determinant na schemacie nie jest przypadkowy. Po pierwsze, na skłonność do oszczędzania wpływa świadomość emerytalna, której istnienie jest warunkiem sine qua non gromadzenia oszczędności emerytalnych. Jest ona również pochodną sytuacji dochodowej gospodarstw domowych, gdyż zgodnie z drugim prawem Engla wydatki na dobra luksusowe lub oszczędności występują dopiero przy dochodzie przekraczającym zaspokojenie podstawowych potrzeb. Po drugie, dostępność produktów emerytalnych jest typowym czynnikiem egzogennym, na który oszczędzający nie ma wpływu, a świadomość emerytalna jest klasycznym czynnikiem endogennym. Potencjał oszczędnościowy może być z kolei warunkowany zarówno przyczynami zewnętrznymi (na przykład sytuacją na rynku pracy), jak i czynnikami wewnętrznymi (na przykład hierarchią potrzeb).

Ekonomia - Wroclaw Economic Review 27/2 (2021)

(C) for this edition by CNS 


\section{Metodyka badań}

Główną osią rozważań podjętych w opracowaniu jest problem badawczy, którego wyrazem jest pytanie o główne przyczyny obserwowanego wykluczenia w dodatkowej części polskiego systemu emerytalnego. W poszukiwaniu odpowiedzi na to pytanie sformułowano cele badawcze opracowania, jakimi są: 1. charakterystyka wykluczenia emerytalnego jako szczególnej formy wykluczenia finansowego, oraz 2. identyfikacja i ocena kluczowych determinant wykluczenia emerytalnego w dodatkowej części polskiego systemu emerytalnego. W ujęciu metodycznym przedstawione rozważania służą zaprezentowaniu argumentów na poparcie tezy, że wykluczenie emerytalne w części dodatkowej systemu emerytalnego jest pochodną niskiej świadomości emerytalnej, niewielkiego potencjału oszczędnościowego oraz związanej z tym niskiej skłonności do oszczędzania wśród Polaków, a także ograniczonej dostępności produktów emerytalnych.

Opracowanie ma charakter epistemologiczny i klasyfikacyjny. W części przeglądowej wykorzystane metody badawcze opierają się na krytycznej analizie piśmiennictwa $\mathrm{w}$ zakresie wykluczenia finansowego (emerytalnego) oraz syntezie płynących z niej wniosków. Przedstawiona w części zasadniczej pracy charakterystyka kluczowych determinant wykluczenia emerytalnego bazuje na meta-analizie rezultatów badań sondażowych podejmujących problematykę świadomości emerytalnej i skłonności do oszczędzania, elementach ekonomicznej analizy prawa oraz analizie danych zastanych.

\section{Determinanty wykluczenia emerytalnego w dodatkowej części polskiego systemu emerytalnego}

\subsection{Dostępność produktów emerytalnych}

Analizując dostępność produktów emerytalnych przez pryzmat wykluczenia emerytalnego w dodatkowej części systemu emerytalnego, na wstępie należy poczynić dwie uwagi. Po pierwsze, produkty emerytalne są produktami finansowymi. Ich dostępność jest więc pochodną szeroko rozumianego wykluczenia finansowego i wskazanych punkcie drugim barier w dostępie do usług finansowych. Wątek ten jest szeroko dyskutowany w krajowym piśmiennictwie (Alińska, 2011; Cichowicz, 2016a, 2016b; Iwanicz-Drozdowska, Błędowski, 2010; Prosiński, 2018). Po drugie, dostępność produktów emerytalnych można rozpatrywać z perspektywy dwóch faz uczestnictwa w systemie emerytalnym. Wyróżnia się wówczas produkty służące gromadzeniu oszczędności emerytalnych oraz produkty służące dekumulacji tych oszczędności (Jakubowski, 2019b).

Ekonomia - Wroclaw Economic Review 27/2 (2021)

(C) for this edition by CNS 
Produkty służące gromadzeniu oszczędności emerytalnych dzieli się na grupowe (PPE i PPK) oraz indywidualne (IKE i IKZE). Analiza rozwiązań legislacyjnych dotyczących tych produktów prowadzi do wniosku, że grono ich odbiorców zostało przez ustawodawcę istotnie ograniczone. Odnosi się to w szczególności do produktów grupowych. $Z$ tych form gromadzenia oszczędności mogą bowiem korzystać jedynie osoby zatrudnione ${ }^{3}$, których pracodawcy prowadzą PPE lub PPK (Prusik, Jakubowski, 2019). Możliwości korzystania z PPE lub PPK zostały zatem pozbawione całe grupy społeczne, takie jak: rolnicy indywidualni, uczestnicy zaopatrzeniowych systemów emerytalnych, osoby samozatrudnione, a także część osób pracujących na umowach cywilno-prawnych. Trzeba jednak zauważyć, że wprowadzenie i stopniowe rozszerzanie obowiązku tworzenia PPK na kolejne grupy podmiotów zatrudniających istotnie wpływa na poszerzenie grona osób mogących korzystać z grupowego oszczędzania na emeryturę.

W przypadku IKE i IKZE nie można mówić wprost o ograniczonej dostępności tych produktów, gdyż formalnie mogą korzystać z nich wszystkie osoby, które ukończyły 16 rok życia ${ }^{4}$. Przyglądając się jednak szczegółowo zasadom uczestnictwa w IKE i IKZE należy zauważyć, że proponowany w ich ramach system zachęt fiskalnych (w szczególności zwolnienie wpłat na IKZE z podatku dochodowego) przeznaczony jest dla osób osiągających dochody i opłacających podatek dochodowy. Dla osób niepracujących lub osiągających niski dochód taki system zachęt nie jest w żaden sposób atrakcyjny (Kawalec i in., 2015).

W fazie konsumpcji wypłata zgromadzonych wcześniej oszczędności emerytalnych może mieć postać: jednorazowej wypłaty całej uzbieranej kwoty, zdefiniowanego ciągu wypłat ratalnych (wypłaty programowej) lub dożywotniego ciągu wypłat (annuitetu) (Jakubowski, 2019c). Co istotne, spośród wymienionych form wypłaty oszczędności emerytalnych tylko annuitet gwarantuje odpowiednią alokację dochodu w cyklu życia i przeciwdziała wykluczeniu emerytalnemu w całym okresie po zakończeniu aktywności zawodowej (Szczepański, 2014). Niezależnie od rozwiązań legislacyjnych stosowanych w ramach IKE, IKZE, PPE i PPK ${ }^{5}$, należy w tym miejscu zauważyć, że w Polsce, podobnie jak w wielu innych krajach europejskich, rynek komercyjnych ubezpieczeń rentowych praktycznie nie

${ }^{3}$ Formalnie PPK obejmuje osoby zatrudnione, które otrzymują wynagrodzenie stanowiące podstawę składek na obowiązkowe ubezpieczenie emerytalno-rentowe, a PPE - pracowników zatrudnionych na podstawie umowy o pracę.

${ }^{4}$ Osoby małoletnie - pod warunkiem uzyskiwania dochodu z pracy wykonywanej na podstawie umowy o pracę.

5 W przypadku IKE, IKZE i PPE ustawodawca daje oszczędzającym swobodę co do formy wypłaty zgromadzonych środków — może być ona dokonywana jednorazowo lub w ratach. W PPK podstawowymi formami wypłaty są: wypłata programowa $75 \%$ zgromadzonych środków przez co najmniej 120 miesięcy, wypłata w formie świadczenia małżeńskiego, wypłata transferowa na lokatę terminową lub wypłata transferowa do zakładu ubezpieczeń na świadczenie okresowe lub dożywotnie (Jakubowski, 2019d).

Ekonomia - Wroclaw Economic Review 27/2 (2021) 
istnieje. Można zatem w tym kontekście mówić o systemowym braku dostępności produktów emerytalnych i wiążącym się z tym wykluczeniem emerytalnym.

\subsection{Potencjał do oszczędzania}

Punktem wyjścia do określenia zdolności do gromadzenia dodatkowych oszczędności emerytalnych jest analiza sytuacji dochodowej gospodarstw domowych ${ }^{6}$. Możliwość oszczędzania na emeryturę pojawia się, gdy suma dochodów uzyskiwanych przez dane gospodarstwo jest wyższa niż jego wydatki na zaspokojenie podstawowych potrzeb konsumpcyjnych. Nadwyżka dochodów może być jednak przeznaczona zarówno na akumulację oszczędności, jak i na realizację potrzeb wyższego rzędu w bieżącym okresie. Stąd na poziom rzeczywistych oszczędności emerytalnych będzie wpływać również krańcowa skłonność do konsumpcji.

$\mathrm{W}$ ujęciu zagregowanym próbę oszacowania potencjału oszczędnościowego polskich gospodarstw domowych można oprzeć na analizie ich dochodów rozporządzalnych oraz wydatków ${ }^{7}$. Z danych publikowanych przez Główny Urząd Statystyczny (2018) wynika, że w 2018 roku w przeciętnym gospodarstwie domowym w Polsce nadwyżka dochodu rozporządzalnego nad wydatkami na całe gospodarstwo wynosiła około 1418 PLN (w przeliczeniu na jedną osobę - około 506 PLN). Wartości te stanowiły więc około 30\% dochodu rozporządzalnego gospodarstwa domowych. Można by zatem wysunąć wniosek o dość dobrej sytuacji dochodowej gospodarstw domowych $\mathrm{w}$ Polsce i związanym $\mathrm{z}$ tym potencjale do gromadzenia dodatkowych oszczędności.

Analizując potencjał oszczędnościowy polskich gospodarstw domowych, warto także zaznaczyć zmiany, jakie odnotowano w poziomie dochodów rozporządzalnych oraz wydatków w ciągu ostatnich kilkunastu lat (por. rysunek 1). W 2018 roku dochód rozporządzalny na osobę w przeciętnym gospodarstwie domowym w Polsce był o ponad 130\% większy od analogicznej wielkości w 2004 roku. W tym czasie wydatki wzrosły o 70,9\%. W konsekwencji w ujęciu względnym udział wydatków $\mathrm{w}$ dochodzie rozporządzalnym zmalał z poziomu około $95 \%$ do około 70\%. Uzasadnionym jest zatem twierdzenie, zgodnie z którym w badanym okresie miał miejsce istotny wzrost potencjału oszczędnościowego polskich gospodarstw domowych.

${ }^{6}$ W tym punkcie opracowania autor wykorzystał skrócone i zaktualizowane o najnowsze dane fragmenty swojej wcześniejszej publikacji (Jedynak, 2017).

${ }^{7}$ Dochód rozporządzalny jest definiowany jako suma bieżących dochodów gospodarstwa domowego pomniejszona o zobowiązania podatkowe obciążające dochody oraz składki na ubezpieczenia społeczne i zdrowotne. W skład dochodu rozporządzalnego wchodzą również dochody niepieniężne, w tym spożycie naturalne oraz towary i usługi otrzymane nieodpłatnie. Wydatki obejmują całość pozycji wydatkowych związanych z zakupem towarów i usług oraz pozostałe wydatki, jak na przykład dary, niektóre podatki (między innymi od spadków i darowizn, od nieruchomości, użytkowanie wieczyste), straty pieniężne, odszkodowania za wyrządzone szkody itp. (GUS, 2018).

Ekonomia - Wroclaw Economic Review 27/2 (2021)

(C) for this edition by CNS 


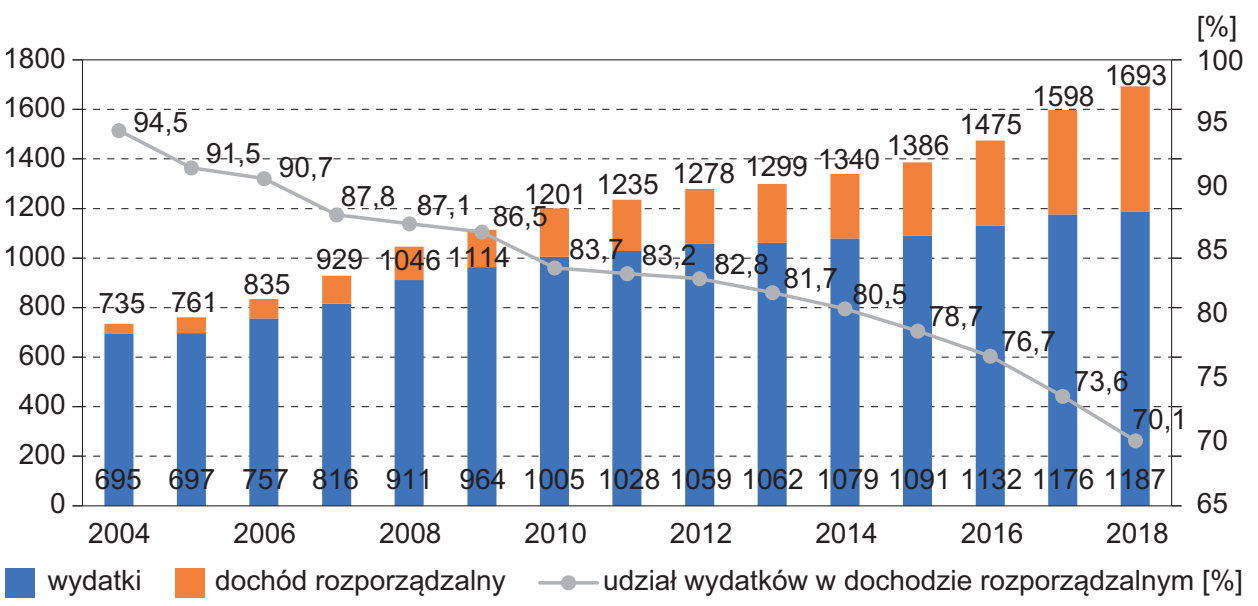

Rysunek 1. Dochód rozporządzalny i wydatki na osobę w gospodarstwach domowych w Polsce w latach 2004-2018 (PLN)

Źródło: opracowanie własne na podstawie (GUS, 2018).

Należy jednak pamiętać, że przytoczone dane GUS są prezentowane na poziomie zagregowanym i prezentują wartości uśrednione dla całej populacji. Są one zatem zniekształcone na skutek zawyżania średniej przez osoby najzamożniejsze ${ }^{8}$. Stąd bardziej adekwatnym — aczkolwiek prezentującym ujęcie subiektywne, a nie obiektywne - narzędziem oceny potencjału oszczędnościowego Polaków wydają się być wyniki badań sondażowych.

Wyniki badań Fundacji Kronenberga (2015) wskazują, że możliwość wygospodarowania jakichkolwiek oszczędności deklaruje około $65 \%$ gospodarstw domowych w Polsce. Na podobny procent wskazują rezultaty badań TNS (2016) zrealizowanych dla Związku Banków Polskich, przy czym miesięczne oszczędności przekraczające 250 PLN odkłada około 13\% gospodarstw domowych. Według ostatniej Diagnozy Społecznej (Czapiński, Góra, 2016) odsetek gospodarstw domowych posiadających jakiekolwiek oszczędności w 2015 roku wynosił 45\%. Gospodarstw domowych posiadających oszczędności przekraczające równowartość ich sześciomiesięcznych dochodów było natomiast około 17\%. Badania koncentrujące się na oszczędnościach emerytalnych jeszcze dobitniej pokazują niski subiektywny potencjał oszczędnościowy Polaków. W badaniach ZUS (2016) wykazano, że 75\% Polaków nie oszczędzało na emeryturę, wskazując przy tym jako główny powód zbyt niski poziom dochodów. Z kolei rezultaty badania zrealizowanego dla Izby Zarządzających Funduszami i Aktywami (2015) wskazują, że aż

8 Jest to widoczne już przy dekompozycji danych GUS. Na przykład przewaga dochodu rozporządzalnego nad wydatkami na osobę w gospodarstwach pracujących na własny rachunek jest ponad 1/3 wyższa niż w gospodarstwach pracowników-robotników. Podobnie różnica między dochodem rozporządzalnym a wydatkami mieszkańców największych miast (powyżej 500 tys. mieszkańców) jest o ponad 260 PLN wyższa niż u mieszkańców wsi. 
95\% pełnoletnich Polaków nie oszczędzało na emeryturę, z czego 53\% jako główny powód wskazało brak wystarczających środków.

\section{3. Świadomość emerytalna}

Termin „świadomość emerytalna”, pomimo częstego stosowania w piśmiennictwie oraz przekazach medialnych (Cichowicz, 2016a; Cichowicz, Rutecka-Góra, 2017; Czapiński and Góra, 2016; Leśna-Wierszołowicz, 2017; Solarz, 2019), nie doczekał się do tej pory ukształtowanej definicji. Podejmując próbę określenia, czym jest świadomość emerytalna, należy zatem odnieść się do szerszych pojęć świadomości finansowej i ubezpieczeniowej. Bazując na koncepcji świadomości ubezpieczeniowej (Szumlicz, 2006) oraz definicji świadomości finansowej (Zdanowska, 2012), świadomość emerytalną w aspekcie dodatkowego systemu emerytalnego można zdefiniować jako stan wiedzy oraz umiejętności pozwalające racjonalnie korzystać z instrumentów dodatkowego zabezpieczenia emerytalnego, odpowiednich do sytuacji danej osoby. Proponowane ujęcie świadomości emerytalnej jest tym samym zbliżone do pojęcia „kompetencji emerytalnych” proponowanego przez Iwonę Olejnik (2016).

Tak rozumiana świadomość emerytalna w ostatnich latach była przedmiotem licznych opracowań eksperckich oraz badań opinii. Wyłania się z nich jednoznaczny obraz niskiej świadomości emerytalnej Polaków. W obszernych badaniach nad świadomością emerytalną Janusz Czapiński i Marek Góra (2016) wskazali, że ponad 7\% pracujących Polaków nie wiedziało, gdzie trafia składka na ubezpieczenie emerytalne, a niecałe $24 \%$ badanych potrafiło powiedzieć, jaki procent ich zarobków stanowi ta składka. W przygotowanym przez ZUS (2016) raporcie Wiedza i postawy wobec ubezpieczeń społecznych na podstawie pogłębionych badań opracowany został indeks wiedzy na temat ubezpieczeń społecznych, według którego respondentów przypisano do jednej z pięciu kategorii: 1 . eksperci ( $0 \%$ badanych); 2. posiadający wiedzę (7\%); 3. średnio zorientowani (33\%); 4. słabo zorientowani (45\%); 5. ignoranci (15\%). W tych samych badanach na pytanie o instrumenty oszczędzania na emeryturę w III filarze $36 \%$ badanych nie potrafiło wskazać żadnej odpowiedzi, 28\% badanych wskazało OFE, 25\% - IKE, 18\% - IKZE, a 10\% - PPE. Podobne wnioski o stanie wiedzy emerytalnej Polaków można wysunąć na podstawie badania Skłonność Polaków do dodatkowego oszczędzania na emeryturę - mit czy rzeczywistość? (TNS Polska, 2016), z którego wynika, że pojęcia „IKE”, „IKZE” i „PPE” były znane odpowiednio 72\%, 38\% i 28\% badanym, ale umiejętność korzystania z tych instrumentów zadeklarowało zaledwie 27\% respondentów (IKE), 14\% (IKZE), oraz 6\% (PPE). Ogólny obraz niskiej świadomości emerytalnej Polaków dopełnia brak wiedzy w zakresie poziomu zabezpieczenia emerytalnego zapewnianego w ramach części bazowej systemu emerytalnego (Cycoń, Jedynak, Płonka, 2020). Jedynie co trzeci Polak (29\%) ocenia,

Ekonomia - Wroclaw Economic Review 27/2 (2021)

(C) for this edition by CNS 
że przyszła emerytura może być niższa o ponad połowę od obecnego wynagrodzenia, 17\% uważa, że emerytura będzie jedynie trochę niższa, a 5\% wierzy, że będzie ona równa lub wyższa (Fundacja Kronenberga, 2016) ${ }^{9}$.

Formułowane spostrzeżenia dotyczące niskiego poziomu świadomości emerytalnej w aspekcie dodatkowego systemu emerytalnego potwierdza również subiektywna ocena „wiedzy emerytalnej” Polaków. W badaniu realizowanym dla NBP $48 \%$ badanych oceniło, że ich wiedza w tym zakresie jest raczej mała lub bardzo mała (Pracownia Badań i Innowacji Społecznych „Stocznia” i Grupa IQS, 2015). Warto jednak zauważyć, że niski poziom wiedzy nie jest tutaj tożsamy $\mathrm{z}$ brakiem chęci do jej pogłębiania — w cytowanych badaniach, na tle innych zagadnień ekonomicznych, potrzeba poszerzania wiedzy emerytalnej była najczęściej wskazywanym obszarem (54\% badanych).

W piśmiennictwie na problem niskiej świadomości emerytalnej w aspekcie dodatkowego oszczędzania zwracają uwagę między innymi Ewa Cichowicz i Joanna Rutecka-Góra (2017), które twierdzą że może ona skutkować niepodejmowaniem działań w zakresie dodatkowego oszczędzania na emeryturę bądź nabywaniem produktów niedostosowanych do indywidualnych możliwości i potrzeb odbiorców. Elwira Leśna-Wierszołowicz (2017) zauważa, że niski poziom wiedzy ekonomicznej Polaków jest jednym z czynników wpływających na brak zaufania do instytucji finansowych oraz oferowanych przez nie produktów (w tym produktów emerytalnych). Małgorzata Solarz (2019) wskazuje natomiast, że osoby o większej świadomości emerytalnej częściej gromadzą dodatkowe pieniądze na przyszłą emeryturę, a zatem podejmują właściwe decyzje emerytalne.

\subsection{Skłonność do oszczędzania na emeryturę}

Skłonność do oszczędzania na emeryturę oznacza zdolność jednostki do odłożenia konsumpcji w czasie aż do zakończenia aktywności zawodowej. Na skłonność do oszczędzania wpływają czynniki o charakterze finansowym, historycznym, psychologicznym i kulturowym, a także konstrukcja systemu emerytalnego (Perek-Białas, 2017). Istotnym czynnikiem jest również wiedza finansowa (Kłopocka, 2018).

Obszerną analizę determinant dobrowolnych oszczędności emerytalnych przeprowadziła Edyta Marcinkiewicz (2018). Wskazała ona między innymi na następujące grupy czynników makro- i mikroekonomicznych wpływających na poziom oszczędności gospodarstw domowych: konstrukcja i hojność systemu obowiązkowego; czynniki dochodowe, finansowe i makroekonomiczna niepewność; uwarunkowania demograficzne i społeczne; edukacja i kompetencje finansowe;

${ }^{9}$ Spośród pozostałych badanych odpowiedź „trudno powiedzieć” wybrało 27\%, 14\% zadeklarowało, że nie myśli o emeryturze, a $8 \%$ stwierdziło, że państwa nie będzie stać na emeryturę i nic nie otrzymają.

Ekonomia - Wroclaw Economic Review 27/2 (2021)

(C) for this edition by CNS 
posiadanie nieruchomości lub kredytu hipotecznego. Dalej, przeprowadzając meta-analizę determinant oszczędzania w dobrowolnych planach emerytalnych, autorka zauważyła, że rezultaty badań empirycznych wskazują na istotny wpływ zmiennych takich jak: wiek, wykształcenie, miejsce zamieszkania, poziom dochodu, obciążenia podatkowe, posiadanie nieruchomości, forma zatrudnienia czy kompetencje finansowe. Marek Góra (2016), wyjaśniając przyczyny niskiej skłonności do oszczędzania w Polsce, wskazuje na doświadczenia historyczne z XX wieku, związane z procesem anihilacji prawnej i ekonomicznej abstraktów, dzięki którym oszczędzanie było możliwe. Po 1989 roku jego zdaniem istotną rolę odegrała natomiast potrzeba odreagowania niedoborów z lat wcześniejszych niski poziom oszczędności wynikał w tym okresie z dużej konsumpcji. Podobną argumentację przytacza również Jolanta Perek-Białas (2017).

W ujęciu empirycznym skłonność Polaków do oszczędzania na emeryturę można szacować na podstawie odpowiedzi, jakich udzielają w sondażowych badaniach opinii. Joanna Adamska-Mieruszewska i Magdalena Mosionek-Schweda (2015) twierdzą, że Polacy wykazują się niską skłonnością do długoterminowego oszczędzania, preferują cele krótkookresowe lub wydają cały dochód rozporządzalny na bieżące potrzeby. Z badań Janusza Czapińskiego i Marka Góry (2016) wynika, że 78,5\% Polaków nie podejmuje żadnych działań mających zapobiec pogorszeniu materialnego standardu życia na emeryturze. Na podobny odsetek nieoszczędzających na emeryturę wskazują również przytaczane wcześniej badania Wiedza i postawy wobec ubezpieczeń społecznych. Raport z badań (Zakład Ubezpieczeń Społecznych i Instytut Spraw Publicznych, 2016) oraz Postawy Polaków wobec finansów (Fundacja Kronenberga, 2015). Warto przy tym zauważyć, że kolejne edycje drugiego z nich wskazują na jeszcze wyższy odsetek nieoszczędzających na emeryturę (w 2016 roku — 89\% w 2017 roku - 92\% a w 2018 roku 91\%), co autorzy raportu kwitują stwierdzeniem: ,emerytura nie jest dla nas celem oszczędzania, reagujemy tylko na zmiany w systemie emerytalnym" (Fundacja Kronenberga 2016; 2017; 2018). Również z badań Skłonność Polaków do dodatkowego oszczędzania na emeryturę - mit czy rzeczywistość? (TNS Polska, 2016) wyłania się obraz niskiej skłonności Polaków do dodatkowego oszczędzania: 86\% badanych w wieku 25-45 lat nie oszczędza na emeryturę. Co więcej, 64\% z tych osób deklaruje, że nie zamierza zacząć oszczędzać w przyszłości.

\section{Wnioski}

Synteza spostrzeżeń poczynionych $\mathrm{w}$ toku przeprowadzonych $\mathrm{w}$ opracowaniu analiz umożliwia sformułowanie kilku istotnych wniosków badawczych.

Po pierwsze, na poziome definicyjnym wskazuje się, że w ramach wykluczenia emerytalnego można wyróżnić wykluczenie z jego części bazowej oraz z części dodatkowej. Pierwsze wiąże się z brakiem środków do życia w okresie staro-

Ekonomia - Wroclaw Economic Review 27/2 (2021)

(C) for this edition by CNS 
ści, drugie skutkuje otrzymywaniem świadczeń emerytalnych poniżej poziomu umożliwiającego utrzymanie wcześniejszego standardu życia. Ponadto wykluczenie emerytalne może dotyczyć wykluczenia w fazie akumulacji uprawnień oraz wykluczenia w fazie konsumpcji, a oba rodzaje wykluczenia nie zawsze są wzajemnie powiązane.

Po drugie, na skalę wykluczenia emerytalnego w części dodatkowej systemu emerytalnego wpływają czynniki zarówno egzo-, jak i endogeniczne względem przyszłych emerytów. Do tych pierwszych należy w szczególności brak dopasowania (na przykład system zachęt fiskalnych) oraz dostępności produktów emerytalnych dla niektórych grup społeczno-zawodowych. W tym kontekście zasięg wdrażanego obecnie systemu pracowniczych planów kapitałowych należy ocenić pozytywnie, aczkolwiek trzeba pamiętać, że program ten nie jest przeznaczony dla wszystkich pracujących i z pewnością nie wyeliminuje całkowicie problemu wykluczenia emerytalnego z części dodatkowej systemu.

Po trzecie, w Polsce mamy do czynienia z systemowym brakiem produktów umożliwiających dożywotnią wypłatę zgromadzonych oszczędności emerytalnych, co przekłada się na powszechne wykluczenie emerytalne w fazie konsumpcji.

Po czwarte, mimo że dane statystyczne pokazują istotny wzrost potencjału oszczędnościowego polskich gospodarstw domowych, ich subiektywna ocena w tym zakresie nadal sugeruje ograniczone możliwości generowania nadwyżek finansowych. Należy również pamiętać, że potencjał do oszczędzania nie jest równoznaczny z potencjałem do oszczędzania na emeryturę. Trudno bowiem oczekiwać, aby gospodarstwa domowe całość nadwyżki finansowej przeznaczały na oszczędności długoterminowe.

Po piąte, w obliczu utrzymującej się od lat niskiej świadomości emerytalnej Polaków oraz niewielkiej skłonności do oszczędzania na emeryturę, nie do przecenienia jest wielokrotnie już podkreślana w piśmiennictwie rola edukacji finansowej, a także wykorzystywanie w konstrukcji produktów emerytalnych dorobków ekonomii behawioralnej i promowanego przez Richarda Thalera i Cassa Sunsteina (2008) podejścia opartego o „libertariański paternalizm”.

Poza sformułowaniem wskazanych wniosków, przeprowadzone w opracowaniu analizy umożliwiły również obronę wysuniętej tezy badawczej. W przekonaniu autora przedstawione rozważania dostarczają wielu argumentów dowodzących, że skala i zasięg wykluczenia emerytalnego w części dodatkowej polskiego systemu emerytalnego są pochodną czynników, które można zakwalifikować do czterech analizowanych kategorii: niskiej świadomości emerytalnej, niewielkiego potencjału oszczędnościowego, związanej z tym niskiej skłonności do oszczędzania Polaków, a także ograniczonej dostępności produktów emerytalnych. Trzeba jednak podkreślić, że wskazane determinanty to makro-kategorie, które obejmują wiele czynników szczegółowych wpływających na poziomie indywidualnym na brak korzystania z produktów dodatkowego zabezpieczenia emerytalnego. 
Na zakończenie warto zauważyć, że przedstawione rozważania teoriopoznawcze mogą stanowić podstawę do pogłębionych analiz empirycznych obejmujących poruszoną problematykę. Szczególnie interesująca wydaje się być kwestia ilościowej kwantyfikacji skali i zasięgu wykluczenia emerytalnego w części dodatkowej systemu emerytalnego. Interesującym kierunkiem dalszych badań jest również analiza szczegółowych czynników wykluczenia emerytalnego wchodzących w skład czterech zaproponowanych makro-kategorii. Wartościowych informacji mogą dostarczyć także badania zorientowane na identyfikację metod i narzędzi przeciwdziałania wykluczeniu emerytalnemu.

\section{Bibliografia}

Adamska-Mieruszewska, J., Mosionek-Schweda, M. (2015). Rozwój indywidualnych oszczędności emerytalnych w kontekście skłonności Polaków do oszczędzania. Praca i Zabezpieczenie Społeczne, 8, 3-19.

Alińska, A. (2011). Problem wykluczenia finansowego w Polsce. Zeszyty Naukowe Uniwersytetu Szczecińskiego. Ekonomiczne Problemy Ustug, 76, 9-22.

Barr, N., Diamond, P. (2014). Reformy Systemu Emerytalnego, Krótki Przewodnik. Warszawa: Polskie Wydawnictwo Ekonomiczne.

Blake, D. (2006). Pension Economics. Chichester: John Willey \& Sons, Ltd.

Chybalski, F. (red.) (2016). Adekwatnosć dochodowa, efektywność i redystrubucja w systemach emerytalnych. Ujęcie teoretyczne, metodyczne i empiryczne. Warszawa: Wydawnictwo C.H. Beck.

Cichowicz, E. (2016a). Działania banków komercyjnych w zakresie edukacji ekonomicznej jako metoda walki z wykluczeniem finansowym. Studia Oeconomica Posnaniensia, 4 (9), 115-135.

Cichowicz, E. (2016b). Wykorzystanie nowoczesnych technologii przez instytucje finansowe w procesie przeciwdziałania wykluczeniu finansowemu. Annales : etyka w życiu gospodarczym, 19 (1), 71-82.

Cichowicz, E., Rutecka-Góra, J. (2017). Świadomość Polaków dotycząca dodatkowego oszczędzania na starość - próba oceny oraz identyfikacji niezbędnych działań. Problemy Polityki Spotecznej. Studia i Dyskusje, 38 (3), 89-103.

Cycoń, M., Jedynak, T., Płonka, M. (2020). Postawy studentów wobec zabezpieczenia ryzyka starości - studium empiryczne. Kraków: Wydawnictwo Uniwersytetu Ekonomicznego w Krakowie.

Czapiński, J., Góra, M. (2016). Świadomość „emerytalna” Polaków. Raport z badania ilościowego. Warszawa: Publikacje Europejskiego Kongresu Finansowego. Data dostępu: 10.12.2019, https://www.efcongress.com/sites/default/files/analizy/raport.pdf.

Dybał, M. (2019). Wykluczenie emerytalne w III filarze. Ekonomia, 25 (4), 101-113.

European Commission. (2008). Financial Services Provision and Prevention of Financial Exclusion. Brussels. Data dostępu: 13.12.2019, https://www.fi-compass.eu/publication/other-resources/financial-services-provision-and-prevention-financial-exclusion.

European Commision. (2018). The 2018 Ageing Report: Economic and Budgetary Projections for the EU Member States (2016-2070). Luxembourg. Data dostępu: 23.12.2019, https://ec.europa. eu/info/publications/economy-finance/2018-ageing-report-economic-and-budgetary-projections-eu-member-states-2016-2070_en.

Ekonomia - Wroclaw Economic Review 27/2 (2021)

(C) for this edition by CNS 
Fundacja Kronenberga przy City Handlowy. (2015). Postawy Polaków wobec finansów. Data dostępu: 8.05.2019, http:/www.citibank.pl/poland/kronenberg/polish/files/postawy_polakow_ wobec_finansow_2015.pdf.

Fundacja Kronenberga przy City Handlowy. (2016). Postawy Polaków wobec finansów. Data dostępu: 8.05.2019, http://www.citibank.pl/poland/kronenberg/polish/files/postawy_polakow_ wobec_finansow_wrzesien_2016.pdf.

Fundacja Kronenberga przy City Handlowy i Fundacji Think! (2017). Postawy Polaków wobec finansów. Data dostępu: 8.05.2019, http://www.citibank.pl/poland/kronenberg/polish/files/postawy_polakow_wobec_finansow_-_raport_fundacji_kronenberga_fundacji_think.pdf.

Fundacja Kronenberga przy City Handlowy i Fundacji Think! (2018). Postawy Polaków wobec finansów. Data dostępu: 8.05.2019, http://www.citibank.pl/poland/kronenberg/polish/files/raport_postawy_2018.pdf.

Główny Urząd Statystyczny, Departament Badań Społecznych. (2018). Budżety Gospodarstw Domowych w 2018 roku. Warszawa. Data dostępu: 19.12.2019, https://stat.gov.pl/download/gfx/portalinformacyjny/pl/defaultaktualnosci/5486/9/13/1/budzety_gospodarstw_ domowych_w_2018.pdf.

Główny Urząd Statystyczny. (2019). Aktywność ekonomiczna ludności Polski II kwartał 2019 roku. Warszawa. Data dostępu: 23.12.2019: https://stat.gov.pl/obszary-tematyczne/rynek-pracy/pracujacy-bezrobotni-bierni-zawodowo-wg-bael/aktywnosc-ekonomiczna-ludnosci-polski-ii-kwartal-2019-roku,4,34.html.

Góra, M. (2003). System emerytalny. Warszawa: Polskie Wydawnictwo Ekonomiczne.

Góra, M. (2016). Oszczędzanie długookresowe, czyli alokacja dochodu w cyklu życia. W J. Rutecka-Góra (red.), Dlugoterminowe oszczędzanie. Podstawy, strategie i wyzwania. Warszawa: Oficyna Wydawnicza SGH.

Góra, M., Rutecka, J. (2013). Elastyczny system emerytalny a potrzebny jego uczestników. Ekonomista, 6, 735-753.

Iwanicz-Drozdowska, M. (red.) (2011). Edukacja i świadomość finansowa. Doświadczenia i perspektywy. Warszawa: Oficyna Wydawnicza SGH.

Iwanicz-Drozdowska, M., Błędowski, P. (2010). Wykluczenie finansowe w Polsce a możliwości przeciwdziałania. Polityka Społeczna, 2.

Jakubowski, S. (2019a). Zniesienie górnej granicy podstawy wymiaru składek na ubezpieczenie emerytalne i rentowe - zagadnienia prawne i ekonomiczne. Polityka Społeczna, 1, 37-40.

Jakubowski, S. (2019b). Gromadzenie środków w pracowniczym planie kapitałowym. Zeszyty Naukowe Politechniki Poznańskiej. Organizacja i Zarządzanie, 80. DOI: 10.21008/j.02399415.2019.080.06.

Jakubowski, S. (2019c). Withdrawal of funds accumulated on the account of employee capital plans participants. Ubezpieczenia Społeczne. Teoria i Praktyka, 4 (143), 41-64.

Jakubowski, S. (2019d). Świadczenia z pracowniczych planów kapitałowych. Rozprawy Ubezpieczeniowe, 2 (32), 97-115.

Jedynak, T. (2014). Charakterystyka systemu emerytalnego w ramach powszechnego ubezpieczenia społecznego. W W. Sułkowska (red.), System ubezpieczeń społecznych. Kraków: Wydawnictwo Uniwersytetu Ekonomicznego w Krakowie.

Jedynak, T. (2017). Luka emerytalna a potencjał do oszczędzania w polskich gospodarstwach domowych. Zeszyty Naukowe Politechniki Poznańskiej. Organizacja i Zarządzanie, 73, 127-143.

Jedynak, T. (2020). Wykluczenie emerytalne z dodatkowej części polskiego systemu emerytalnego - analiza skali i zasięgu zjawiska. Ubezpieczenia Społeczne. Teoria i Praktyka, 3.

Kawalec, S., Błażuk, K., Kurek, M. (2015). Jak mobilizować dodatkowe oszczędności emerytalne? Warszawa: Capital Strategy. 
Kłopocka, A. (2018). Skłonność gospodarstw domowych do oszczędzania a wiedza finansowa. Bank i Kredyt, 5, 461-492.

Kolek, A., Wojewódka, M. (2019a). Poziom partycypacji w pracowniczych planach kapitatowych. Warszawa: Instytut Emerytalny, Kancelaria Wojewódka i Wspólnicy. Data dostępu: 28.12.2019, http://www.instytutemerytalny.pl/wp-content/uploads/2019/11/IE-WiW-raport-Poziom-partycypacji-w-PPK-_listopad-2019.pdf.

Komisja Nadzoru Finansowego. (2019a). Biuletyn Roczny. Rynek PPE 2018. Data dostępu: 21.12.2019, https://www.knf.gov.pl/?articleId=66736\&p_id=18.

Komisja Nadzoru Finansowego. (2019b). Informacje liczbowe o rynku IKE za 2018 rok. Data dostępu: 21.12.2019, https://www.knf.gov.pl/?articleId=64783\&p_id=18.

Kondzielnik, O., Majka, K. (2019) Ryzyko wykluczenia emerytalnego pokolenia Y. Rozprawy Ubezpieczeniowe, 1 (31), 86-99.

Leśna-Wierszołowicz, E. (2017). Świadomość emerytalna Polaków. Prace Naukowe Uniwersytetu Ekonomicznego we Wrocławiu, 475, 159-169.

Marcinkiewicz, E. (2018). Uwarunkowania rozwoju dobrowolnych programów emerytalnych perspektywa makro- i mikroekonomiczna. Łódź: Wydawnictwo Politechniki Łódzkiej.

OECD. (2013). Pensions at a Glance 2013: OECD and G20 Indicators. OECD Publishing. Data dostępu: 7.01.2020, https://op.europa.eu:443/en/publication-detail/-/publication/d72c5336-1b1246c9-a8cf-59bb470628f7.

OECD. (2017). Pensions at a Glance 2017: OECD and G20 Indicators. OECD Publishing. Data dostępu: 29.10.2019, https://doi.org/10.1787/pension_glance-2017-en.

Olejnik, I. (2016). Zabezpieczenie emerytalne. Modele i determinanty zachowań polskich gospodarstw domowych. Poznań: Wydawnictwo Uniwersytetu Ekonomicznego w Poznaniu.

Perek-Białas, J. (2017). Zaufanie obywateli do systemu emerytalnego a skłonność do oszczędzania na starość. Ubezpieczenia Społeczne. Teoria i praktyka, 2 (133), 75-93.

Pracownia Badań i Innowacji Społecznych „Stocznia” i Grupa IQS dla Departamentu Edukacji i Wydawnictw NBP. (2015). Stan wiedzy i świadomości ekonomicznej Polaków. Data dostępu: 7.01.2020, https://www.nbportal.pl/_data/assets/pdf_file/0006/54528/Diagnoza-stanu-wiedzy-i-swiadomosci-ekonomicznej-Polakow-2015.pdf.

Prosiński, J. (2018). Determinanty wykluczenia finansowego w Polsce. Prace Naukowe Uniwersytetu Ekonomicznego we Wrocławiu, 532, 304-312.

Prusik, A., Jakubowski, S. (2019). Art. 2 ust. 1 pkt 18. W Ustawa o Pracowniczych Planach Kapitałowych. Komentarz. Warszawa: Wolters Kluwer.

Rutecka, J. (2014). Dodatkowe zabezpieczenie emerytalne — charakterystyka i czynniki rozwoju. Prace Naukowe Uniwersytetu Ekonomicznego we Wrocławiu, 342, 256-266.

Rutecka, J. (red.) (2015). Dodatkowy system emerytalny w Polsce - Diagnoza i rekomendacje zmian. Warszawa: Towarzystwo Ekonomistów Polskich.

Solarz, M. (2019). Świadomość emerytalna jako warunek skutecznego zarządzania ryzykiem starości. Przedsiębiorczość i Zarzadzanie, 20 (1), 49-62.

Szczepański, M. (2014). Zarządzanie ryzykiem długowieczności w polskim systemie emerytalnym. Zeszyty Naukowe Uniwersytetu Szczecińskiego. Finanse, Rynki Finansowe, Ubezpieczenia, 65, 731-744.

Szczepański, M. (2016). Analiza i ocena proponowanych zmian ustawowego wieku emerytalnego w Polsce. Finanse, Rynki Finansowe, Ubezpieczenia, 1 (79), 739-751.

Szumlicz, T. (2005). Ubezpieczenia społeczne. Teoria dla praktyki. Bydgoszcz-Warszawa: Oficyna Wydawnicza Branta.

Szumlicz, T. (2006). Atrybuty świadomości i przezorności ubezpieczeniowej. Rozprawy Ubezpieczeniowe, 1, 21-26.

Thaler, R., Sunstein, C.R. (2008). Nudge: Improving Decisions about Health, Wealth, and Happiness. New Haven, CT: Yale University Press.

Ekonomia - Wroclaw Economic Review 27/2 (2021)

(C) for this edition by CNS 
TNS dla Związku Banków Polskich. (2016). Wybrane aspekty oszczędzania w polskim społeczeństwie. Data dostępu: 6.05.2019, https://zbp.pl/public/repozytorium/wydarzenia/images/wrzesien_2016/oszczedzanie/oszczdzanie___wyniki_badania.pdf.

TNS Polska dla Izby Zarządzających Funduszami i Aktywami. (2015). Polacy wobec oszczędzania na emeryturę. Warszawa. Data dostępu: 11.12.2019, https:/www.izfa.pl/download/pobierz/ polacy-wobec-oszczedzania-na-emeryture.

TNS Polska dla Nationale-Nederlanden. (2016). Skłonność Polaków do dodatkowego oszczędzania na emeryturę - mit czy rzeczywistość? Data dostępu: 19.12.2019, http://www.tnsglobal.pl/ coslychac/files/2016/03/Sklonnosc-do-oszczedzania-na-emeryture-2016-03-04.pdf.

Uścińska, G. (2011). Dodatkowe systemy emerytalne w regulacjach UE: konsekwencje dla państw europejskich. Polityka Spoleczna, 9, 1-7.

Zakład Ubezpieczeń Społecznych i Instytut Spraw Publicznych. (2016). Wiedza i postawy wobec ubezpieczeń społecznych. Raport z badań. Warszawa. Data dostępu: 7.01.2020, https://www. zus.pl/documents/10182/44573/Raport+wiedza+system+emerytalny/040bd2a1-094a-4d979d77-e0bddc19e845.

Zdanowska, M. (2012). Świadomość finansowa w Polsce. Zeszyty Naukowe Uniwersytetu Szczecińskiego. Współczesne Problemy Ekonomiczne. Globalizacja. Liberalizacja. Etyka, 5, 213-225. 
Ekonomia - Wroclaw Economic Review 27/2 (2021) (C) for this edition by CNS 